\title{
Molecular studies on the genus Muticaria Lindholm, 1925 (Pul- monata Clausiliidae) from the Maltese Islands
}

\author{
Maria Stella Colomba ${ }^{*}$, Armando Gregorini', David P. Cilia ${ }^{2}$, Fabio Liberto ${ }^{3}$, Agatino Reitano ${ }^{4}$ \& Ignazio \\ Sparacio 5
}

${ }^{1}$ Università di Urbino, Department of Biomolecular Sciences, via Maggetti 22, 61029 Urbino, Pesaro-Urbino, Italy; e-mail: mariastella.colomba@uniurb.it, armando.gregorini@uniurb.it

229, Triqil-Palazz 1-Ahmar, Santa Venera, Malta

${ }^{3}$ Via del Giubileo Magno 93, 90015 Cefalù, Italy; e-mail: fabioliberto@yahoo.it

${ }^{4}$ Natural History Museum, via degli Studi 9, 97013 Comiso, Ragusa, Italy; e-mail: tinohawk@yahoo.it

${ }^{5}$ Via Principe di Paternò 3, 90143 Palermo, Italy; e-mail: edizionidanaus@gmail.com

${ }^{*}$ Corresponding author

ABSTRACT

KEY WORDS

The present study has been carried out with focus on Muticaria macrostoma group from the Maltese Islands to characterize and define, from a molecular standpoint, their identity and relationships with topotypical Sicilian Muticaria (i.e. M. syracusana, M. neuteboomi, M. cyclopica and M. brancatoi). Molecular study included amplification of 16S rDNA (ca. $300 \mathrm{bp}$ ) and COI (ca. $700 \mathrm{bp}$ ) gene partial sequences which were used for single and combined gene analysis by Bayesian Inference to achieve the phylogenetic reconstructions with the highest posterior probabilities. Obtained results showed that, within M. macrostoma group, the taxa mamotica and oscitans can be elevated to the specific rank, thus bringing to three the Maltese Muticaria species, i.e. M. macrostoma, M. mamotica, and M. oscitans; whereas scalaris may be considered a subspecies, or even a synonim. Present findings confirmed the validity of the Sicilian species $M$. syracusana, M. neuteboomi, M. cyclopica and M. brancatoi. Furthermore, the populations of the Sicilian and Maltese Muticaria seem to belong to two different levels of differentiation. Finally, we have also examined some Lampedusa populations but the position of this genus still remains to be clarified. In particular, it is confirmed that Lampedusa and Muticaria are different genera, but at present, the relations within the Lampedusa group need further studies to be analysed in details.

\section{Received 25.07.2018; accepted 03.10.2018; published online 28.12.2019}

Proceedings of the 4th International Congress on Biodiversity "Man, Natural Habitats and Euro-Mediterranean Biodiversity", November, 17th-19th 2017 - Malta

\section{INTRODUCTION}

The genus Muticaria Lindholm, 1925 (Clausiliidae Alopiinae Medorini) comprises xeroresistant and calcicolous molluscs, distributed in Central-eastern and South-eastern Sicily and Maltese Islands.
At present, four Muticaria species can be found on the Sicilian territory: M. syracusana (Philippi, 1836), M. neuteboomi Beckmann, 1990, M. brancatoi Colomba, Reitano, Liberto, Giglio, Gregorini et Sparacio, 2012 and M. cyclopica Liberto, Reitano, Giglio, Colomba et Sparacio, 2016; while 
only M. macrostoma Cantraine, 1835 is reported for the Maltese Islands (Bank, 2017; Bank \& Neubert, 2019).

As far as concerns the distribution of Sicilian Muticaria species, M. syracusana, locus typicus Siracusa (Philippi, 1836), occurs along the entire coast embracing Siracusa province; M. neuteboomi, locus typicus Cave d'Ispica, Ragusa province (Beckmann, 1990), inhabits a quite broad area including Siracusa, Ragusa, Caltanissetta and Catania provinces, and generally occurs at higher altitudes than those reported for M. syracusana; $M$. brancatoi is known only for the localities of description, i.e. Cugnolungo (type locality), Spinagallo, Vallone Moscasanti (Siracusa) (Colomba et al., 2012); and, finally, M. cyclopica, type locality Castello di Eurialo (Epipoli, Siracusa), is currently reported only for Epipoli, a hill about $150 \mathrm{~m}$ high, very close to the modern city of Siracusa (Liberto et al., 2016).

On the other hand, the Maltese species includes morphologically different populations that have been variously considered different species, or subspecies or simple morphs (see also Holyoak, 1986; Beckmann, 1992; Giusti et al., 1995; Nordsieck, 2007). Currently, one species with four subspecies is accepted (Bank, 2017; Bank \& Neubert, 2019):

M. macrostoma macrostoma, locus typicus Malta (Cantraine, 1835), reported for Gozo, Comino, Cominotto and Malta;

M. macrostoma scalaris (L. Pfeiffer, 1850), locus typicus: Malta (L. Pfeiffer, 1850), inhabiting a very limited area on the Northwestern coast of Malta (Tal-Blata, Mistra Bay = St. Paul's Bay);

M. macrostoma oscitans (Charpentier, 1852), locus typicus: Malta (Charpentier, 1852), reported for Gozo and Malta;

M. macrostoma mamotica (Gulia, 1861), locus typicus: "in insula Gaulos" (Gulia, 1861), occurring in a very limited area on the Munxar side of Xlendi Valley in Gozo.

Numerous studies have been conducted on Maltese Muticaria, especially on the morphology of the shell and the genital organs (see Giusti et al., 1995 and cited bibliography), with often conflicting results on the taxonomic interpretation, also due to the presence of hybridization phenomena between some populations (Giusti et al. 1995; Cilia et al., 2012).

Taking into account available literature data and results obtained in previous studies carried out by this research team (Colomba et al., 2010; 2012; Liberto et al., 2016), we decided to further investigate on this group (Colomba et al., 2017). In particular, we focused on M. macrostoma from the Maltese Islands in order to characterize and define, from a molecular standpoint, their taxonomic status and the relationships with Sicilian Muticaria. In this work on Muticaria, we also included Lampedusa imitatrix (O. Boettger, 1879) specimens from Malta to study the relationships between these two genera that share part of the same area in the islands of the Sicilian Channel. Indeed, the genus Lampedusa O. Boettger, 1877 is distributed also in the Pelagie Islands (Sicilian Channel) with L. lopadusae lopadusae (Calcara, 1846) from Lampedusa and $L$. lopadusae nodulosa (Monterosato, 1892) from Lampione.

Lampedusa and Muticaria were also investigated using genetic data (sequencing of a fragment of the mitochondrial large ribosomal subunit $16 \mathrm{~S}$ rRNA, and the nuclear internal transcriber spacer 1, ITS-1 rRNA) with a study available online as a bioRxiv preprint (Fiorentino et al., 2017, http://dx. doi.org/10.1101/208348).

Our results, compared also with available data, will be employed to achieve a better understanding of the speciation and dispersal phenomena of the populations of these interesting alopiine clausiliids and provide useful indications for their taxonomy.

\section{MATERIAL AND METHODS}

\section{Samples and Collection sites}

Two to five specimens per each population were employed for the study. Representatives of all subspecies of M. macrostoma sampled in different locality on the Maltese Islands, in addition to the topotypical populations of Sicilian Muticaria species, were analysed, along with specimens of Lampedusa imitatrix from Malta. Data on samples and collection sites, including the acronyms of the different examined populations, localities and GenBank Accession Numbers are reported in Table 1.

As seen in Table 1, in some cases where the specimens initial identification was not certain (ei- 
ther at the subspecific or specific level) the samples were labelled separately and differently, i.e. macrostoma $\mathrm{x}$ oscitans (see also acronyms). Each collection site or locality is named in the original languages (i.e. Italian or Maltese).

\section{DNA extraction}

Samples were stored separately at $-20^{\circ} \mathrm{C}$ in test tubes. For each individual, a piece of foot tissue was used for total DNA extraction (by Wizard Genomic DNA Purification Kit, Promega). Voucher specimens were stored in the laboratory of Cytogenetics and Molecular Biology (University of Urbino, via Maggetti 22). Fragments of $16 \mathrm{~S}$ rDNA (251-297 bp): and COI (529-660 bp) sequences were amplified using the primer pairs: MED16F/R (forward: 5'-ACTGTGCAAAGGTAGCATAA3'/reverse: 5'-CCAACATCGAGGTCACAA-3') designed by Colomba and LCO_1490/HCO2198 as in Folmer et al. (1994). PCR cycles were as follows: $95{ }^{\circ} \mathrm{C}$ for $5 \mathrm{~min} ; 95^{\circ} \mathrm{C}$ for $1 \mathrm{~min}, 55^{\circ} \mathrm{C}$ for $1 \mathrm{~min}, 72^{\circ} \mathrm{C}$ for $1 \mathrm{~min}$ ( 30 cycles $) ; 72^{\circ} \mathrm{C}$ for $5 \mathrm{~min}$ (16S rDNA); $95^{\circ} \mathrm{C}$ for $5 \mathrm{~min}$; $95^{\circ} \mathrm{C}$ for $1 \mathrm{~min}, 42$ ${ }^{\circ} \mathrm{C}$ for $1 \mathrm{~min}, 72{ }^{\circ} \mathrm{C}$ for $1 \mathrm{~min}(35$ cycles $) ; 72{ }^{\circ} \mathrm{C}$ for $5 \mathrm{~min}(\mathrm{COI})$. To remove primers and unincorporated nucleotides, the amplified products were purified by the Wizard SV gel and PCR Clean-up kit (Promega). Sequencing of the purified PCR products was carried out using automated DNA sequencers at Eurofins MWG Operon (Germany). GenBank Accession Numbers for all sequences generated in this study are listed in Table 1. Homologous sequences of Clausilia bidentata (Strǿm, 1765) (AF012082; JX911288), Medora garganensis (A.J. Wagner, 1918) (KC833909; KC853248), Arianta arbustorum (Linnaeus, 1758) (JF717810; MF140994) and Massylea vermiculata (O.F. Müller,



Figure 1. Distribution map of Muticaria and Lampedusa in the Maltese Islands (Holyoak, 1986 modified): white dots: distribution of M. macrostoma macrostoma; blue dots: sampling localities of M. macrostoma macrostoma; red dot: distribution and sampling localities of $M$. macrostoma scalaris; white and black dots: distribution of morphologically intermediate populations between M. macrostoma macrostoma and M. macrostoma oscitans; black dots: distribution of M. macrostoma oscitans; green dots: sampling locaties of M. macrostoma oscitans; purple star: distribution and sampling locality of $M$. macrostoma mamotica; triangles: distribution of L. imitatrix imitatrix; blue A: sampling localities of L. imitatrix imitatrix; rhombus: distribution of L. melitensis; square: distribution of L. imitatrix gattoi. 


\begin{tabular}{|c|c|c|c|c|c|}
\hline $\begin{array}{l}\text { Taxon (initial } \\
\text { classification) }\end{array}$ & Collection site & $\begin{array}{l}\text { Voucher } \\
\text { label }\end{array}$ & Coordinates & $\begin{array}{l}\text { Species (revised } \\
\text { classification) }\end{array}$ & $\begin{array}{c}\text { GenBank Accession } \\
\text { Number }\end{array}$ \\
\hline M. m. macrostoma 1 & $\begin{array}{l}\text { St. Paul's Bay, } \\
\text { Mistra, Malta }\end{array}$ & MH & $\begin{array}{l}35^{\circ} 57^{\prime} 26^{\prime \prime} \mathrm{N} \\
14^{\circ} 23^{\prime} 27^{\prime \prime} \mathrm{E}\end{array}$ & M. macrostoma & $\begin{array}{l}\text { MN395320, MN395321; } \\
\text { MN395351, MN395353 }\end{array}$ \\
\hline M. m. macrostoma 2 & $\begin{array}{l}\text { St. Paul's Bay, } \\
\text { Mistra, Malta }\end{array}$ & MR & $\begin{array}{l}35^{\circ} 57^{\prime} 18^{\prime \prime} \mathrm{N} \\
14^{\circ} 23^{\prime} 08^{\prime \prime} \mathrm{N}\end{array}$ & M. macrostoma & $\begin{array}{l}\text { MN395322, MN395323; } \\
\text { MN395352, MN395354 }\end{array}$ \\
\hline M. m. mamotica & $\begin{array}{l}\text { Il-Fekruna promon- } \\
\text { tory, Munxar, Gozo }\end{array}$ & MAM & $\begin{array}{l}36^{\circ} 01^{\prime} 59^{\prime \prime} \mathrm{N} \\
14^{\circ} 13^{\prime} 48^{\prime \prime} \mathrm{E}\end{array}$ & M. mamotica & $\begin{array}{l}\text { MN395326, MN395328; } \\
\text { MN395357, MN395358 }\end{array}$ \\
\hline M. m. oscitans & Mdina, Malta & MW2 & $\begin{array}{l}35^{\circ} 53^{\prime} 09^{\prime \prime} \mathrm{N} \\
14^{\circ} 24^{\prime} 03^{\prime \prime} \mathrm{E}\end{array}$ & M. mamotica & MN395329; MN395361 \\
\hline $\begin{array}{l}\text { M. m. macrostoma } \\
\mathrm{x} \text { oscitans }\end{array}$ & $\begin{array}{l}\text { Baharija, Rabat, } \\
\text { Malta }\end{array}$ & MAS & $\begin{array}{l}35^{\circ} 53^{\prime} 47^{\prime \prime} \mathrm{N} \\
14^{\circ} 20^{\prime} 50^{\prime \prime} \mathrm{E}\end{array}$ & M. oscitans & $\begin{array}{l}\text { MN395334, MN395332; } \\
\text { MN395364, MN395365 }\end{array}$ \\
\hline M. m. macrostoma 3 & $\begin{array}{l}\text { Wied il-Kbir, } \\
\text { Qormi, Malta }\end{array}$ & QC & $\begin{array}{l}35^{\circ} 51^{\prime} 56^{\prime \prime} \mathrm{N} \\
14^{\circ} 28^{\prime} 21^{\prime \prime} \mathrm{E}\end{array}$ & M. oscitans & $\begin{array}{l}\text { MN395336, MN395337 } \\
\text { MN395367, MN395368 }\end{array}$ \\
\hline M. m. oscitans & $\begin{array}{l}\text { Hagar Qim, } \\
\text { Qrendi, Malta }\end{array}$ & HQ & $\begin{array}{l}35^{\circ} 49^{\prime} 36^{\prime \prime} \mathrm{N} \\
14^{\circ} 26^{\prime} 30^{\prime \prime} \mathrm{E}\end{array}$ & M. oscitans & $\begin{array}{l}\text { MN395331, MN395335; } \\
\text { MN395363, MN395362 }\end{array}$ \\
\hline M. m. oscitans & Mdina, Malta & MW1 & $\begin{array}{l}35^{\circ} 53^{\prime} 09^{\prime \prime} \mathrm{N} \\
14^{\circ} 24^{\prime} 03^{\prime \prime} \mathrm{E}\end{array}$ & M. oscitans & MN395333; MN395366 \\
\hline $\begin{array}{l}\text { M. m. macrostoma } \\
\mathrm{x} \text { oscitans }\end{array}$ & $\begin{array}{l}\text { Fort St. Elmo, } \\
\text { Valletta, Malta }\end{array}$ & MAO & $\begin{array}{l}35^{\circ} 54^{\prime} 07^{\prime \prime} \mathrm{N} \\
14^{\circ} 31^{\prime} 04^{\prime \prime} \mathrm{E}\end{array}$ & M. oscitans & $\begin{array}{l}\text { MN395330, MN395327; } \\
\text { MN395359, MN395360 }\end{array}$ \\
\hline M. m. scalaris & $\begin{array}{l}\text { St. Paul's Bay, } \\
\text { Mistra, Malta }\end{array}$ & MS & $\begin{array}{l}35^{\circ} 57^{\prime} 35^{\prime \prime} \mathrm{N} \\
14^{\circ} 23^{\prime} 41^{\prime \prime} \mathrm{E}\end{array}$ & M. m. scalaris & $\begin{array}{l}\text { MN395324, MN395325; } \\
\text { MN395355, MN395356 }\end{array}$ \\
\hline $\begin{array}{l}\text { Lampedusa } \\
\text { (imitatrix) imitatrix }\end{array}$ & $\begin{array}{l}\text { Fomm Ir-Rih, } \\
\text { Rabat, Malta }\end{array}$ & LIM & $\begin{array}{l}35^{\circ} 54^{\prime} 11^{\prime \prime} \mathrm{N} \\
14^{\circ} 20^{\prime} 03^{\prime \prime} \mathrm{E}\end{array}$ & $\begin{array}{l}\text { Lampedusa } \\
\text { (imitatrix) imitatrix }\end{array}$ & $\begin{array}{l}\text { MN395310, MN395313; } \\
\text { MN395344, MN395345 }\end{array}$ \\
\hline $\begin{array}{l}\text { Lampedusa } \\
\text { (imitatrix) imitatrix }\end{array}$ & $\begin{array}{l}\text { Fort St. Elmo, } \\
\text { Valletta, Malta }\end{array}$ & LIMS & $\begin{array}{l}35^{\circ} 54^{\prime} 07^{\prime \prime} \mathrm{N} \\
14^{\circ} 31^{\prime} 04^{\prime \prime} \mathrm{E}\end{array}$ & $\begin{array}{l}\text { Lampedusa } \\
\text { (imitatrix) imitatrix }\end{array}$ & $\begin{array}{l}\text { MN395311, MN395312; } \\
\text { MN395346, MN395347 }\end{array}$ \\
\hline M. syracusana & $\begin{array}{l}\text { Roman Amphitheatre } \\
\text { Siracusa, Italy }\end{array}$ & SYR & $\begin{array}{l}37^{\circ} 04^{\prime} 28^{\prime \prime} \mathrm{N} \\
15^{\circ} 16^{\prime} 45^{\prime \prime} \mathrm{E}\end{array}$ & M. syracusana & HQ696868; HQ696869 \\
\hline M. neuteboomi & $\begin{array}{l}\text { Cava di Ispica, } \\
\text { Ragusa, Italy }\end{array}$ & NEU & $\begin{array}{l}36^{\circ} 51^{\prime} 11^{\prime \prime} \mathrm{N} \\
14^{\circ} 50^{\prime} 14^{\prime \prime} \mathrm{E}\end{array}$ & M. neuteboomi & HQ696866; HQ696867 \\
\hline M. brancatoi & $\begin{array}{l}\text { Spinagallo, } \\
\text { Siracusa, Italy }\end{array}$ & SPI & $\begin{array}{l}37^{\circ} 00^{\prime} 12^{\prime \prime} \mathrm{N} \\
15^{\circ} 10^{\prime} 50^{\prime \prime} \mathrm{E}\end{array}$ & M. brancatoi & $\begin{array}{l}\text { MN395314, MN395315, } \\
\text { MN395316; KC550118, } \\
\text { KC550119, KC550120 }\end{array}$ \\
\hline M. cyclopica & $\begin{array}{l}\text { Epipoli, Castello } \\
\text { Eurialo, Siracusa, } \\
\text { Italy }\end{array}$ & EPI & $\begin{array}{l}37^{\circ} 05^{\prime} 20^{\prime \prime} \mathrm{N} \\
15^{\circ} 13^{\prime} 49^{\prime \prime} \mathrm{E}\end{array}$ & M. cyclopica & $\begin{array}{l}\text { MN395317, MN395318, } \\
\text { MN395319; MN395348, } \\
\text { MN395349, MN395350 }\end{array}$ \\
\hline
\end{tabular}

Table 1. Data on specimens employed for the present study including initial taxonomic classification, sampling localities, voucher labels, coordinates, final revised taxonomic classification and GenBank Accession Numbers.

1774) (JF277389; JF802033) were used as OutGroups (OGs).

\section{Phylogenetic analyses}

All sequences were visualized with BioEdit Sequence Alignment Editor 7 (Hall, 1999), aligned with the ClustalW option included in this software and refined by eye. Genetic distances were assessed as $p$ distances. Gene sequences were analysed by either single or combined analysis. Phylogenetic analyses were conducted in BEAST 1.6.1 (Drum- mond \& Rambaut, 2007) using the *BEAST implementation (Heled \& Drummond, 2010). A series of initial runs was performed to optimize priors and runtime parameter choices to obtain effective sampling sizes (ESS) above 500 for all estimated parameters. Parameter estimates were gained from combined log files. The best-fit evolution model of nucleotide substitution resulted in $\mathrm{HKY}+\mathrm{G}$ for both genes with empirical base composition; the Yule Process tree prior for mitochondrial data with piecewise linear population size model was applied with a UPGMA-generated tree as the starting point. Five 
single runs were combined with the LogCombiner 1.6.1 implemented in the software package BEAST. Trees from all runs were combined to produce an ultrametric consensus tree using TreeAnnotator 1.6.1. The first $10^{5}$ trees were discarded as burnin. Support for nodes is expressed as posterior probabilities.

\section{RESULTS}

Partial sequences of the 16S rDNA and COI molecular markers of all the sampled specimens of Muticaria from Maltese Islands were analyzed along with the homologous sequences of the four Sicilian species of Muticaria in addition to those of two populations of Lampedusa imitatrix.

The cladogram in figure 1, as a result of $16 \mathrm{~S}$ rDNA sequences analysis, shows three mega-clus- ters: Lampedusa imitatrix (in green), three clusters of the Maltese Muticaria taxa (in red), including $M$. macrostoma+scalaris, M. oscitans and M. mamot$i c a$, and four clusters (in blue) of the Sicilian Muticaria species.

The obtained phylogenetic tree of the Maltese and Sicilian taxa are clearly distinct, and the high posterior probability values are a confirmation of the reliability of this reconstruction.

As a result of COI sequences analysis, the clusters are exactly the same as those already described, and the output does not change (Fig. 2).

After Combined analyis (Fig. 3) as well, clusters result exactly the same as those described before.

Finally, to add further information on the genetic distance between the examined taxa, genetic distances have also been calculated. In particular, for both 16S rDNA and COI partial sequences, $\mathrm{p}$ distances between all the sampled populations (Tables

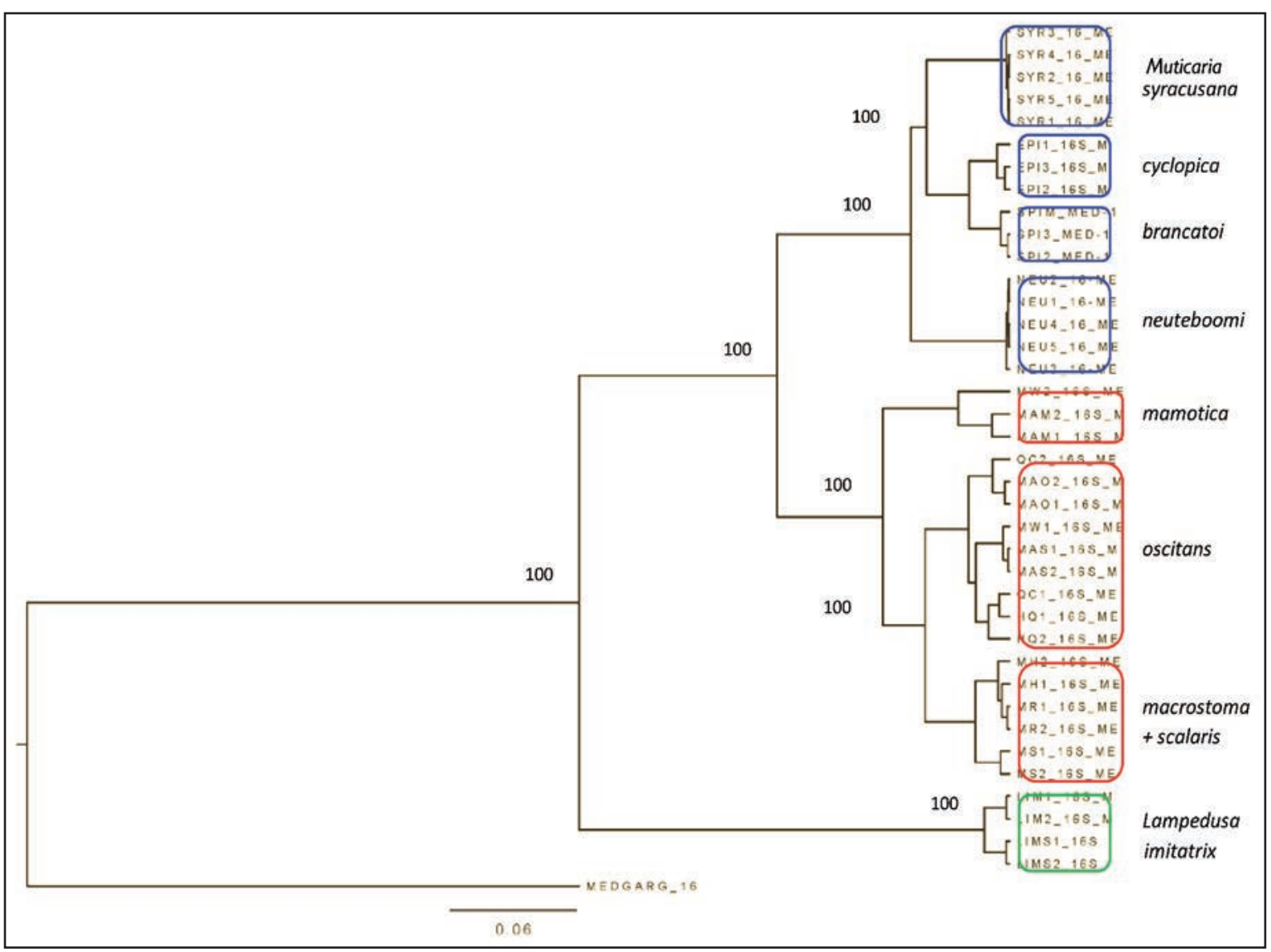

Figure 1. Phylogenetic reconstruction by Bayesian Inference obtained by single gene analysis of 16S rDNA partial sequences. Posterior Probabilities are reported on nodes. Maltese Muticaria taxa are shown in red clusters, Sicilian Muticaria taxa are shown in blue clusters and Lampedusa imitatrix specimens in green clusters. 
$2,4)$ and between the populations grouped by species (Tables 3, 5) were assessed.

\section{DISCUSSION}

The results obtained from this work, continuing the studies conducted on the Muticaria genus (Colomba et al., 2010, 2012, 2017; Liberto et al., 2016), suggest that the taxa hitherto considered as subspecies of M. macrostoma may (with the exception of "scalaris") be elevated to the specific rank, on the basis of both the phylogenetic trees topography and genetic $p$ distance values.

In particular, if we consider $16 \mathrm{~S}$ rDNA $\mathrm{p}$ distances $>0.2$ as delimiting taxa at the genus level and from 0.1 to 0.05 as delimiting taxa at the species rank, it is possible to maintain that, as far as concerns the Maltese taxa: (i) M. mamotica appears very different from M. macrostoma (ca. $\mathrm{p}=0.103$ ) and M. oscitans $(\mathrm{p}=0.092)$;

(ii) M. oscitans can be elevated to the species rank with respect to $M$. macrostoma $(\mathrm{p}=0.072)$ and M. mamotica $(\mathrm{p}=0.092)$, whereas

(iii) "scalaris" seems to fall into M. macrostoma $(\mathrm{p}=0.032)$ leaving at the moment unsolved the question of whether to consider it a subspecies or a synonym.

the result of the molecular data for the populations marked with the voucher labels MAO and MAS (apparently hybrid populations, M. macrostoma $\mathrm{x}$ oscitans, see Table 1) is significant of the difficulties that occur in the study of this group by a morphological and anatomical approach only. The shape and the ribs of the shell of these two populations did not allow a sure taxonomic classification. Molecular data indicated that they



Figure 2. Phylogenetic reconstruction by Bayesian Inference obtained by single gene analysis of COI partial sequences. Maltese Muticaria taxa are shown in red clusters, Sicilian Muticaria taxa are shown in blue clusters and Lampedusa imitatrix specimens in green clusters. 
were two populations attributable to $M$. oscitans clade. The molecular diversity of $M$. oscitans (see also Fiorentino et al., 2017) requires further studies.

Sicilian Muticaria species are confirmed with $M$. syracusana being clearly distinct from $M$. neuteboomi $(\mathrm{p}=0.066)$ and a little less from $M$. brancatoi $(\mathrm{p}=0.046)$; interestingly, $16 \mathrm{~S}$ rDNA $\mathrm{p}$ distance between $M$. brancato $i$ and $M$. cyclopica is quite low $(\mathrm{p}=0.021)$. This is most likely because the two taxa are very similar in the (short) part of the $16 \mathrm{~S}$ rDNA sequence analyzed, but the topography of the cladogram shows the taxa clearly distinct.

A very similar picture emerges from the analysis of COI $p$ distances. Briefly, from COI amplicons the validity of the Maltese species M. macrostoma, M. mamotica and M. oscitans is confirmed. For the Sicilian species, in addition to M. syracusana and
M. neuteboomi, COI sequences also reveled a significant distance between $M$. brancatoi and $M$. $c y$ clopica (0.626). These molecular data with the known morphological and anatomical differences (Colomba et al., 2012; Liberto et al., 2016) confirm that two different species can be considered.

It should also be noted on all the cladograms examined, how the Sicilian Muticaria populations remain distinct from the Maltese ones, clearly indicating two geographical differentiation levels.

Based on the 16S rDNA distances, Lampedusa is confirmed as a different genus $(\mathrm{p}=0.206)$ from Muticaria. COI distances confirm that they are different genera (Lampedusa imitatrix - Muticaria macrostoma group $\mathrm{p}$ distance $=0.139 ;$ L. imitatrix Sicilian Muticaria species $\mathrm{p}$ distance $=0.261$ ) considering also the known morphological and anatomical differences (Giusti et al., 1995).

The molecular and morphological data obtained

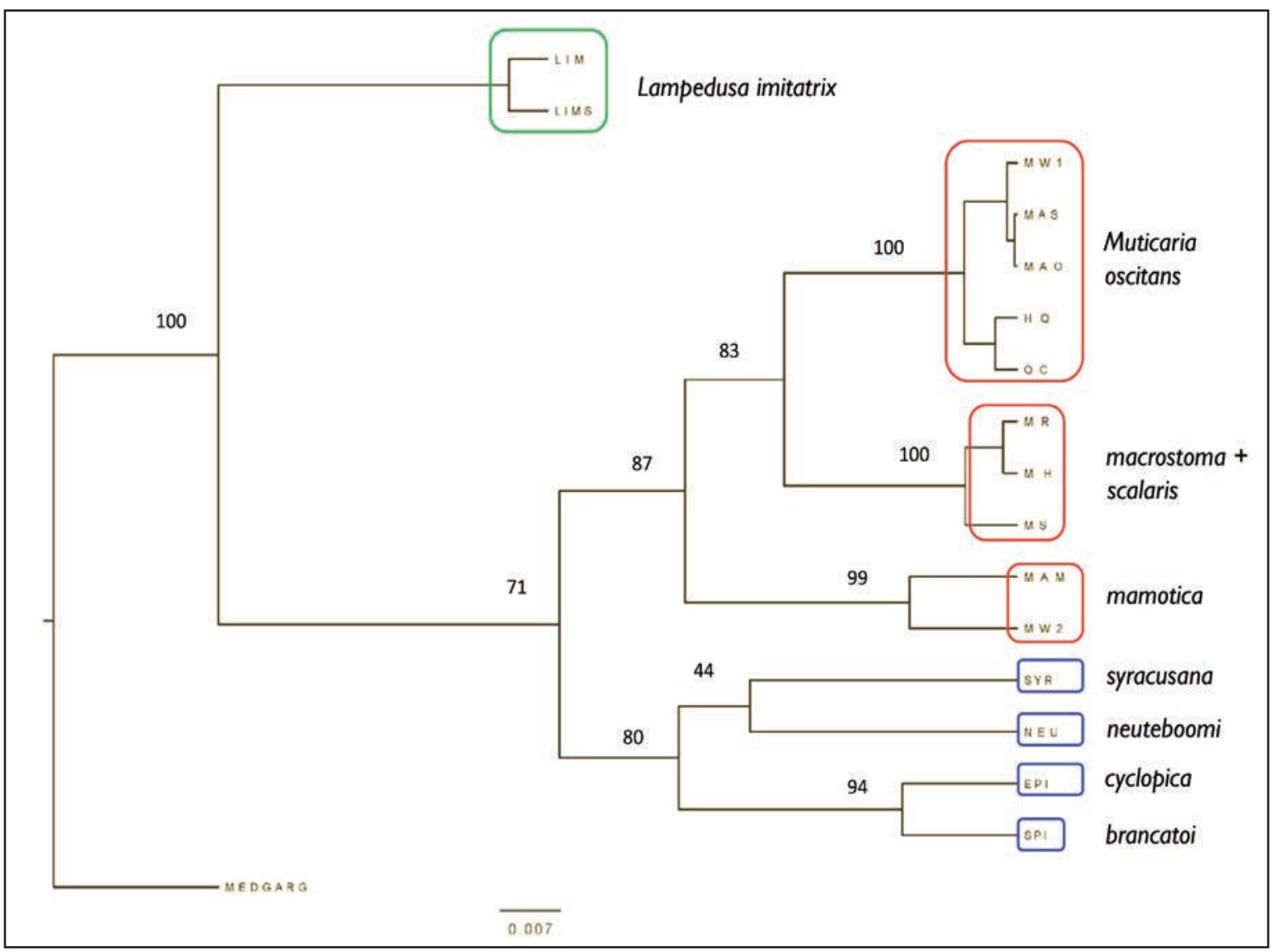

Figure 3. Phylogenetic reconstruction by Bayesian Inference obtained by combined gene analysis of $16 \mathrm{~S}$ and COI rDNA partial sequences (i.e. concatenated analysis). Posterior Probabilities are reported on nodes. Maltese Muticaria taxa are shown in red clusters, Sicilian Muticaria taxa are shown in blue clusters and Lampedusa imitatrix specimens in green clusters. 


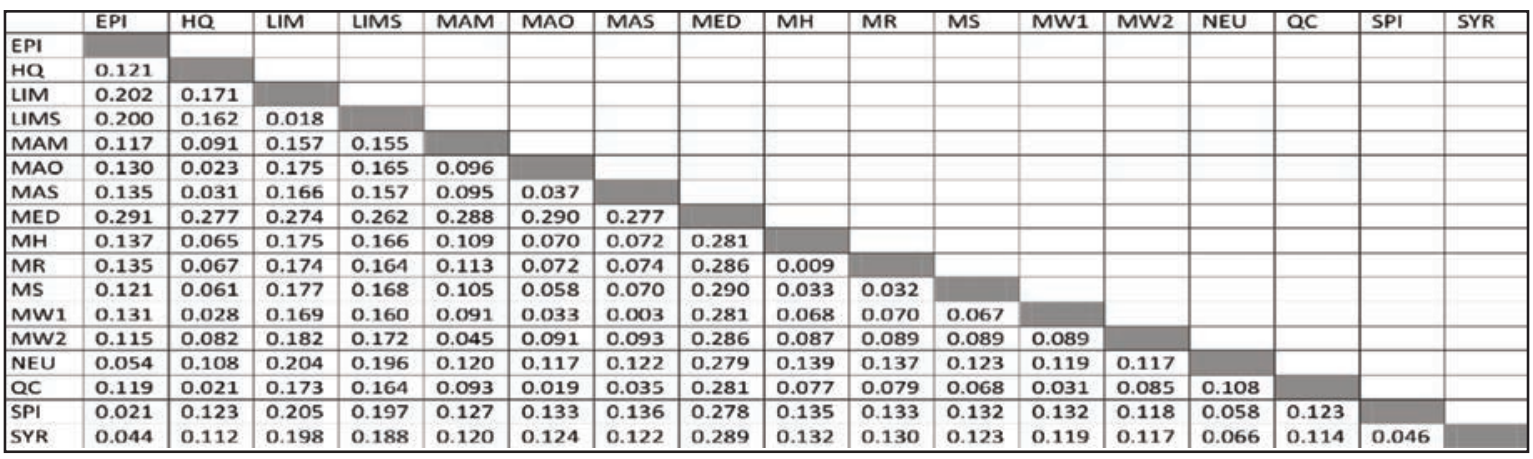

Table 2. $\mathrm{p}$ distances between all the sampled populations calculated on 16S rDNA partial sequences (acronyms in Table 1).

\begin{tabular}{|l|l|l|l|l|l|l|l|l|l|l|}
\hline & M. cyclopica & M. oscitans & L. imitatrix & M. mamot. & Med. garg. & M. macrost & scalaris & M. neuteb. & M. brancat. & M. syrac. \\
\hline M.cyclopica & & & & & & & & & & \\
\hline M. oscitans & 0.127 & & & & & & & & & \\
\hline L. imitatrix & 0.201 & 0.166 & & & & & & & & \\
\hline M. mamot. & 0.116 & 0.092 & 0.163 & & & & & & & \\
\hline Med. garg. & 0.291 & 0.281 & 0.268 & 0.287 & & & & & & \\
\hline M. macrost. & 0.136 & 0.072 & 0.170 & 0.103 & 0.284 & & & & & \\
\hline scalaris & 0.121 & 0.065 & 0.173 & 0.100 & 0.290 & 0.032 & & & & \\
M. neuteb. & 0.054 & 0.115 & 0.200 & 0.119 & 0.279 & 0.138 & 0.123 & & \\
\hline M. brancat. & 0.021 & 0.129 & 0.201 & 0.124 & 0.278 & 0.134 & 0.132 & 0.058 & \\
\hline M. syrac. & 0.044 & 0.118 & 0.193 & 0.119 & 0.289 & 0.131 & 0.123 & 0.066 & 0.046 \\
\hline
\end{tabular}

Table 3. 16S rDNA p distances between all the sampled populations arranged by species.



Table 4. p distances between all the sampled populations calculated on COI partial sequences (acronyms in Table 1).

\begin{tabular}{|c|l|l|l|l|l|l|l|l|l|l|}
\hline & M.cyclopica & M. oscitans & L. imitatrix & M. mamot. & Med. garg. & M. macrost & scalaris & M. neuteb. & M. brancat. & M. syrac. \\
\hline M.cyclopica & & & & & & & & & & \\
\hline M. oscitans & 0.597 & & & & & & & & & \\
\hline L. imitatrix & 0.607 & 0.131 & & & & & & & & \\
\hline M. mamot. & 0.590 & 0.093 & 0.152 & & & & & & & \\
\hline Med. garg. & 0.614 & 0.174 & 0.191 & 0.182 & & & & & & \\
\hline M. macrost. & 0.595 & 0.074 & 0.145 & 0.094 & 0.171 & & & & & \\
\hline scalaris & 0.589 & 0.071 & 0.143 & 0.093 & 0.177 & 0.019 & & & & \\
\hline M. neuteb. & 0.610 & 0.119 & 0.158 & 0.138 & 0.183 & 0.125 & 0.126 & & & \\
\hline M. brancat. & 0.626 & 0.253 & 0.275 & 0.275 & 0.241 & 0.259 & 0.256 & 0.252 & & \\
\hline M. syrac. & 0.614 & 0.130 & 0.150 & 0.134 & 0.191 & 0.121 & 0.130 & 0.121 & 0.254 \\
\hline
\end{tabular}

Table 5. COI $\mathrm{p}$ distances between all the sampled populations arranged by species. 
by Fiorentino et al. (2017, bioRxiv unpublished preprint) show Lampedusa and Muticaria as two different genera, and Muticaria as a monophyletic clade divided into three geographical lineages (Sicilian, Maltese and Gozitan populations).

\section{CONCLUSIONS}

All the above data allow us to draw taxonomic conclusions, even partial, on the Muticaria populations examined for their greater knowledge and protection.

In conclusions, our findings suggest that:

(i) within Maltese Muticaria is possible to elevate to the specific rank "mamotica" and "oscitans", thus bringing to three the Maltese Muticaria species i.e. M. macrostoma, M. mamotica and $M$. oscitans; whereas M. macrostoma scalaris would remain a subspecies;

(ii) as far as concerns the Sicilian species, $M$. syracusana, M. neuteboomi, M. brancatoi and $M$. cyclopica are confirmed;

(iii) the Sicilian and Maltese Muticaria populations seem to belong to two geographical differentiation levels;

(iv) Lampedusa and Muticaria are two different genera.

The high level of differentiation found within this group is a consequence both of the complex biogeographical history of this region and of strict connection between the geological (calcareous) nature of the soil these molluscs live in and the scarce vagility of the specimens, leading to islandlike distributional patterns characterized by high levels of endemism.

All this requires a greater commitment in the protection and management of these land molluscs and the environments in which they live.

\section{REFERENCES}

Beckmann K.-H., 1990. Beitrage zur Kenntnis der Landmolluskenf auna Sizilien mit der Beschreibung von Muticaria neuteboomi spec. nov. (Gastropoda Pulmonata: Clausiliidae). Basteria, 54: 75-85.

Beckmann K.-H., 1992. Catalogue and bibliography of the land- and freshwater molluscs of the Maltese Is- lands, the Pelagie Islands and the Isle of Pantelleria. Heldia, 2: 1-60.

Bank R.A., 2017. Fauna Europaea. Checklist of the land and freshwater Gastropoda of Europe. Last update: February 18th, 2017

Bank R.A. \& Neubert E., 2019. MolluscaBase. Checklist of land and freshwater Gastropoda of Europe. Last update: November, 182019 Accessed at http://www. molluscabase.org/

Cantraine F., 1835. Mollusques - M. Cantraine fait parvenir à l'Accadémie la noticie suivante, contenant les diagnoses ou descriptions succinctes de quelques espèces nouvelles de mollusques. Bulletins de l'Academie royale des Sciences Belles-Lettres de Bruxelles, 2: 380-401.

Charpentier J. De, 1852. Essai d'une classification naturelle des Clausilies. Journal de Conchyologie, 3: 357408, Pls. 11.

Cilia D.P., Sciberras A., Sciberras J. \& Pisani L., 2012. Terrestrial gastropods of the minor islets of the Maltese Archipelago (Mollusca Gastropoda). Biodiversity Journal, 3: 543-554.

Colomba M.S., Gregorini A., Liberto F., Reitano A., Giglio S. \& Sparacio I., 2010. Molecular analysis of Muticaria syracusana and M. neuteboomi from Southeastern Sicily (Gastropoda, Pulmonata, Clausiliidae). Biodiversity Journal, 1: 7-14.

Colomba M.S., Gregorini A., Liberto F., Reitano A., Giglio S. \& Sparacio I., 2012. Additional data on the genus Muticaria Lindholm, 1925 with description of new species (Gastropoda Pulmonata Clausiliidae). Biodiversity Journal, 3: 251-258.

Colomba M. S., Gregorini A., Cilia D., Liberto F., Reitano A. \& Sparacio I., 2017. Molecular studies on the genus Muticaria (Pulmonata: Clausiliidae) from the Maltese Islands. Abstract of 4th International Congress on Biodiversity "Man, Natural Habitats and Euro-Mediterranean Biodiversity", Malta, 17-19th November 2017. Bulletin of the entomological Society of Malta, 9: 44.

Drummond A.J. \& Rambaut A., 2007. BEAST: Bayesian evolutionary analysis by sampling trees. BMC Evolutionary Biology, 7: Article number $214 \mathrm{https}$ ://doi. org/10.1186/1471-2148-7-214

Fiorentino V., Salomone N., Schembri P.J., Manganelli G., Giusti F., 2017. The radiation of alopiine clausiliids in the Sicilian Channel (Central Mediterranean): phylogeny, patterns of morphological diversification and implications for taxonomy and conservation of Muticaria and Lampedusa. bioRxiv preprint first posted online Oct. 26, 2017. doi: http://dx.doi.org/ 10.1101/208348.

Folmer O., Black M., Hoeh W., Lutz R. \& Vrijenhoek R., 1994. DNA primers for amplification of mitochondrial Cytochrome $\mathrm{C}$ oxidase subunit I from diverse 
metazoan invertebrates. Molecular Marine Biology and Biotechnology, 3: 294-299.

Giusti F., Manganelli G. \& Schembri P.J., 1995. The nonmarine molluscs of the Maltese Islands. Monografie Museo Regionale Scienze Naturali, Torino, 15: 1-607.

Gulia G., 1861. Tentament Ichthyologiae Melitensis sistens methodo naturali stirpium objectis nonnullis observationibus genera et speciebus, a recentioribus de re zoologica scriptoribus admissas insularum Melitae quos Gavinus Gulia M.D. disciminare potuit. Melitae, $71+v i+2$ pp.

Heled J. \& Drummond A.J., 2010. Bayesian Inference of Species Trees from Multilocus Data. Molecular Biology and Evolution, 27: 570-580 doi: 10.1093/molbev/msp274

Hall T.A., 1999. BioEdit: A User-Friendly Biological Sequence Alignment Editor and Analysis Program for Windows 95/98/NT. Nucleic Acids Symposium Series, 41: 95-98.
Holyoak D.T., 1986. Biological species-limits and systematics of the Clausiliidae (Gastropoda) of the Maltese Islands. Journal of Conchology, 32: 211220.

Liberto F., Reitano A., Giglio S., Colomba M.S. \& Sparacio I., 2016. Two new Clausiliidae (Gastropoda Pulmonata) of Sicily (Italy). Biodiversity Journal, 7: 365-384.

Nordsieck H., 2007. Worldwide Door Snails (Clausiliidae), recent and fossil. Conch Books, Hackenheim, $214 \mathrm{pp}$.

Pfeiffer L., 1850. Descriptions of thirty new species of Tornatellina, Cylindrella and Clausilia, from the collection of Hugh Cuming, Esq. Proceedings of the Zoological Society of London, 1849: 134-141.

Philippi R.A., 1836. Enumeratio molluscorum Sicilae cum viventium tum in tellure tertiaria fossilium, quae in itinere suo observavit. Berolini, xiv+267 pp., Pls. $1-12$. 